\title{
A Formal Analysis of Selected Proofs by Aquinas for the Uniqueness of God
}

TOMASZ KAKOL, BYDGOSZCZ

\section{Introduction}

In this paper I analyze selected proofs for the uniqueness of God, reconstructed from the writings of St. Thomas Aquinas. ${ }^{1}$ Contemporary philosophers are interested mainly in his proofs for the existence of God, but, interestingly, Aquinas himself attached no lesser importance to the proofs for the uniqueness of God: for example, in Summa Contra Gentiles he gives us seventeen arguments for this claim.

We shall not consider problems such as the Holy Trinity, though this topic is not without interest for philosophical explorations (which could amount in this case mainly to analyzing purported compatibility of the Trinitarian thesis with monotheism). We shall reconstruct the arguments using proofs for the uniqueness of God stated directly by Aquinas, but sometimes we will have to appeal to different texts he authored, mainly in order to justify certain premises.

Although Aquinas's proofs for the uniqueness of God are manifold, some of them are similar; so, we can distinguish the following types of arguments: (1) proofs in which Aquinas assumes the identity of essences of God-like beings (the first argument from Summa Theologiae, the third from Scriptum Super Libros Sententiarum and the ninth from Summa Contra Gentiles); next, (2) proofs in which he uses the principle of the identity of indiscernibles (whose formulation people usually ascribe to Leibnizhere the relevant arguments are: the second proof from Summa Theologiae, Scriptum Super Libros Sententiarum and Summa Contra Gentiles); (3) the proofs from Summa Contra Gentiles in which Aquinas uses the notion of specification (specificare) and designation (designare); (4) proofs in which he assumes that for every quality $P$ there is something that for every object having $P$ this thing is the unique cause of $P$ in them; (5) proofs where

\footnotetext{
1 This article is a revised fragment of my master dissertation entitled Proofs for the uniqueness of God in the writings of St. Thomas Aquinas, supervised by Prof. Jerzy Perzanowski and defended at Nicholas Copernicus University in Torun in 2001. Portion of this paper has been published in Polish as Kakol 2006.
} 
Aquinas assumes some kind of teleological order in the world; and (6) proofs in which the central notion is motion, in an Aristotelian sense.

Not all the proofs are, of course, interesting from the logico-philosophical point of view. Hereafter I shall focus on the arguments of the first type. ${ }^{2}$

Now one should explain why we shall consider in the first case the proofs from S.th., though - as we know-this is the earliest of Aquinas's works analyzed here. The rationale is that this is probably the most popular of Thomas's texts, yet, on the other hand, the Angelic Doctor conceived it only as a concise manual. That is why S.th. alone cannot, as we will be able to see later, give us the full picture of Aquinas's attacks on the problems we are interested in here. Other Aquinas's texts are considered here according to their chronological order.

\section{Arguments of the first type}

Summa theologica

I, q. 11, a. 3

The first argument

Manifestum est enim quod illud|For it is evident, that something, unde aliquid singulare est hoc in virtue of which a given indialiquid, nullo modo est multis vidual is the very particular thing, communicabile. Illud enim unde cannot be shared by many things Socrates est homo, multis in any way. Something, in virtue communicari potest; sed id unde of which Socrates is a man, can

2 The description of editions of Thomas's writings is in the bibliography. Translation of Aquinas's texts is done by the author, if not otherwise indicated. The translation base for Summa Theologiae is Marietti's edition from 1894, hence, suitable texts are cited according to this edition. Thomas's works are cited in the following way: Summa Theologiae is denoted by S.th.; Scriptum Super Libros Sententiarum is denoted by Scriptum; De Ente et Essentia is denoted by De ente; Summa Contra Gentiles is denoted by Scg. "Dist." denotes distinction, "c."- chapter (caput), "q."- question, "a."article. In the case of S.th. only the first part (pars prima) of this work is used, whereas in the case of Scriptum and Scg - only the first book; therefore, we shall omit this information in the subsequent quotes. Next, we shall give page number, column number and line number. Example: $S$. th. q.1, a.1, p.15, col.2, 1. 1-10 denotes Marietti's edition of Summa theologiae from 1894, part one, question 1, article 1, page 15, column 2, lines 1-10.

As to the chronology of St. Thomas's works, see Weisheipl 1983. 
est hic homo, non potest be shared by many, yet somecommunicari nisi uni tantum. Si thing, in virtue of which he is the ergo Socrates per id esset homo, very particular man, can pertain per quod est hic homo, sicut non to but one thing. So if Socrates possunt esse plures Socrates, ita were a man in virtue of the same non possent esse plures homines. thing by which he is that very parHoc autem convenit Deo. Nam ticular man, then, as it is not posipse Deus est sua natura, ut supra sible that many Socrateses exist, ostensum est (q.3, a.3). Secundum it would not be possible that igitur idem est Deus et hic Deus. many men could exist. Yet this Impossibile est igitur esse plures pertains to God. For God is His deos.

(S.th. q.11, a.3, p.60, col.2, 1.48$50-\mathrm{s} .61$, col.1, 1.1-12)

own essence (q.3, a.3). So $\mathrm{He}$ is God in virtue of the same thing by which $\mathrm{He}$ is that particular God. Therefore, it is impossible that many Gods exist.

In q.3, a.3 Thomas argues that in God there is no difference between subject (individual, suppositum) and essence ${ }^{3}$. He justifies it claiming that in God there is no composition of matter and form (q.3, a.2). Essence contains only that which pertains to the definition of the species, yet in particulars composed of matter and form there is individual matter along with accidents, which does not enter into definition, and hence, is not contained in essence. But it seems that it does not follow that pure form is essence provided that there are certain accidents which are independent of matter. Thomas writes about accidents which individuate matter (materia individualis cum accidentibus omnibus individuantibus ipsam- q. 3, a. 3, p. 19, col. 2, 1. 2-4 ). Yet are there any accidents independent of matter? The text we consider does not answer the question. Even if God is His essence, it does not suffice for proving His uniqueness, for we would have to assume

\footnotetext{
${ }^{3}$ In the explored texts Aquinas treats such terms as essentia, quidditas and natura as synonyms. In De ente c. 1, p.10, 1.24-25 we read that essence is something "through which a thing pertains to its proper kind or species" (per quod res constituitur in proprio genere vel specie), and is this that is denoted by this thing's definition. The problem is that if essence is defined independently of division of the universe into kinds and species, then it is hardly distinguishable from the proper accidents (accidentia propria). On the other hand, if - in order to define essence - we must have this division first, we are not allowed to make such division by appealing to essential properties.
} 
that God-like beings have the same essence. Let 'ess' be a functional term; 'ess $(x)$ ' should be read as ' $x$ 's essence'. Let ' $\mathrm{D}(x)$ ' denote ' $x$ is a God-like being'. That every such an object is its essence is expressed by:

$$
\forall x(\mathrm{D}(x) \rightarrow \operatorname{ess}(x)=x)
$$

So there is at most one such object, if there is only one essence of such objects, i.e.

$$
\forall x \forall y(\mathrm{D}(x) \wedge \mathrm{D}(y) \rightarrow \operatorname{ess}(x)=\operatorname{ess}(y))
$$

A question arises: how to interpret formulae 'ess $(x)=x$ ' or 'ess $(x)=$ ess $(y)^{\prime}$ '? The thinker familiar with the contemporary philosophy can easily be misled here. For example, Alvin Plantinga in his Does God Have A Nature? presents the following reductio of the thesis 'God is His essence': Essence is a set of certain properties, God is His essence, hence, God is a set of certain properties, which amounts to the claim that there is no God (Plantinga 1980, p. 47). But the proper conclusion is of course that Aquinas had something different in mind.

Substance is that which is not in something else as in a subject; its opposite is accident, which directly or indirectly is in substance. Another account is: $\mathrm{P}$ is $x$ 's accident if and only if $\mathrm{P}$ is not included in $x$ 's essence. $x$ 's accidents can be either necessary for $x$ (accidentia propria) or contingent; it is also said that the first ones "follow from essence" or that they have a "cause" in that essence.

From this description ${ }^{4}$ Aquinas concludes that God is His essence provided that there is no accident in Him. Therefore, the expression 'Deus est sua essentia' means simply that there is no accident in God.

This last claim is investigated by Aquinas in q.3, a.6 ("Are there any accidents in God?"). In the first argument Thomas holds that the relationship between suppositum and accident is an exemplification of the relationship between potency and act, whereas God is a pure act. In the second one he says that nothing can be superadded to pure existence, whereas God is a pure existence. The third one is:

\footnotetext{
${ }^{4}$ Although it is problematic at least in that the term causa has a very broad meaning here. I translate it consequently as a "cause", but in many cases it should be understood as a "reason".
} 
Omne quod est per se, prius est Everything, which is by itself, is eo quod est per accidens. Unde prior to what is by accident. cum Deus sit simpliciter primum Hence, since God is by His own ens, in eo nihil potest esse per nature the prime being, nothing accidens. Sed nec accidentia per can be in Him by accident. And se in eo esse possunt; sicut also proper accidents cannot be in risibile est per se accidens Him, as, for example, being able hominis; quia huiusmodi to laugh is man's proper accident; accidentia causantur ex principiis because an accident of that kind subiecti. In Deo autem nihil has its cause in the subject's prinpotest esse causatum, cum sit ciples. Yet nothing, which is in causa prima. Unde relinquitur God, can have any cause, since quod in Deo nullum sit accidens. God is the first cause. Hence, it (S.th. q.3, a.6, p.22, col.2, 1.31-41) follows that there is no accident in God.

The crucial premise of that reasoning was formulated by Aquinas in q.3, a.4:

Quia quidquid est in aliquo, quod It is necessary that everything in est praeter essentiam eius, oportet something else, and outside of the esse causatum: vel a principiis essence of that in which it is, has a essentiae, sicut accidentia cause: either the principles of espropria consequentia speciem; ut sence will be that cause, as proper risibile consequitur hominem, et accidents following from the specausatur ex principiis cies, as being able to laugh pertains essentialibus speciei: vel $a b$ to man, and the essential principles aliquo exteriori, sicut calor in of the species are its cause, or someaqua causatur ab igne. (S.th. q.3, thing external to it will be that a.4, p.20, col.1, 1.42-49) cause, as, e.g., fire is the cause of heat in water.

The principle stating that "what is outside of the essence, has a cause", is not explained in S.th.; furthermore, that God does not have any cause, need not entail that nothing in God has any cause. As we shall see, more information related to this problem is in $S c g$.

Scriptum super libros Sententiarum 
I, dist. II, q.1, a.1

The third argument

Praeterea, eius in quo non differt suum esse ${ }^{5}$ et sua quidditas, non potest participari quidditas sua sive essentia, nisi et esse participetur. Sed quandocumque dividitur essentia alicuius per participationem, essentia eadem secundum rationem et non secundum idem esse. Ergo impossibile est eius in quo non differt essentia et esse, essentialem participationem dividi vel multiplicari. Tale autem est Deus (...). (Scriptum I, dist.II, q.1, a.1, p.60, 1.27-36)
What is more, the essence of the thing, in which there is no difference between the very thing's essence and its existence, cannot be participated in, if the existence were not be participated in. Yet whenever one's essence is divided by participation, the same essence according to its concept is participated in, but not according to its existence. So, it is impossible for something in which there is no difference between essence and existence to be divided by essential participation or multiplied. Yet God is a thing of that kind (...).

This argument seems to be very unclear. Let me reformulate it in the following way: essence is "divided by participation" if there are at least two beings having that essence; yet these beings differ from one another in their existence, so they participate in that essence as having the same essence, yet not as existing. Hence, there cannot be more beings having the same essence, if this essence does not differ from their existence. More formally, using symbols 'ess' and ' $\mathrm{D}$ ' introduced above, and introducing term 'ex $(x)$ ' (' $x$ 's existence'), one can prove that there is at most one Godlike being. The theorem that is to be proved is that of the uniqueness of God:

$$
\forall x \forall y(\mathrm{D}(x) \wedge \mathrm{D}(y) \rightarrow x=y)
$$

The sentence "Sed quandocumque..." can be expressed by:

$$
\forall x \forall y(x \neq y \wedge \operatorname{ess}(x)=\operatorname{ess}(y) \rightarrow \operatorname{ex}(x) \neq \operatorname{ex}(y))
$$

${ }^{5}$ Following tradition (in particular, the tradition of existential thomism), I usually translate esse as 'existence'. 
Different things, participating in the same essence, differ according to their existence.

Next, God is such that His essence is His existence, that is:

$$
\forall x(\mathrm{D}(x) \rightarrow \operatorname{ess}(x)=\operatorname{ex}(x))
$$

One can prove that from (3) and (4), (!) does not follow. The proof will be valid if we add formula (2) to the premises, i.e.

$\forall x \forall y(\mathrm{D}(x) \wedge \mathrm{D}(y) \rightarrow \operatorname{ess}(x)=\operatorname{ess}(y))$

So we have the same assumption as we had in the first argument of S.th., that is, that God-like objects have the same essence. ${ }^{6}$

It is worth noticing that our interpretation of the sentence "Sed quandocumque..." can be seen as not coinciding with Aquinas's intention. One could suggest the following, alternative account: if $x$ and $y$ participate in a certain essence, then they participate in the same essence according to its concept, but not in the same essence according to its existence, i.e. $x$ and $y$ have the same essence according to its concept, yet not according to its existence.

We can make use of the following analogy:
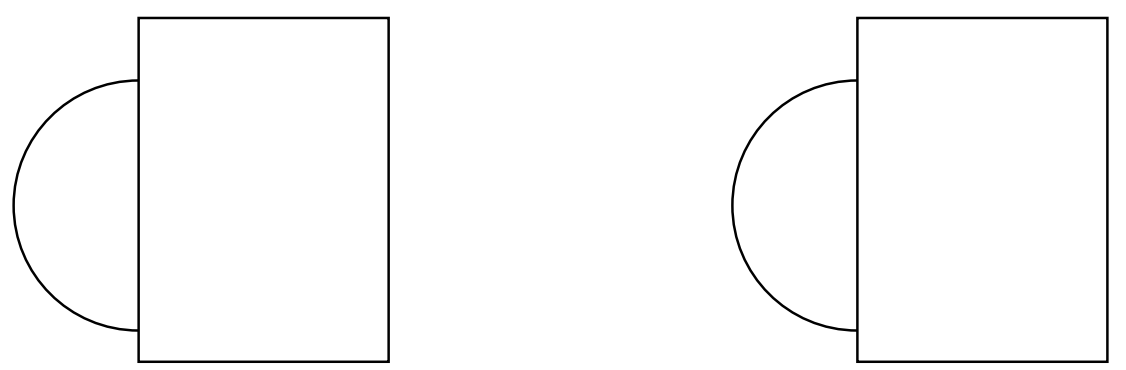

We can say that both circles have "the same color according to the uncovered color". Assume that, in addition to that, we know that they have "different color according to the covered color". It is easy to deduce from that that the following is true of at least one circle: the color covered is not identical to the color uncovered. Moreover, it is true of one circle that the

\footnotetext{
${ }^{6}$ Formal proofs can be found in Appendix.
} 
color of full circle is not identical to the color covered. Similarly, Thomas is right in concluding that it is true of some being that its essence is not identical to its existence.

But it seems that these phrases expressing relative identity can be eliminated, for they suggest that existence is a part (or an aspect) of essence; whereas Thomas in S.th., q.3,a.4 (Utrum in Deo sit idem essentia et esse) argues for theorem (4) in his first argument as follows: God's existence cannot be outside of His essence, for otherwise either (i) it has to be "caused" by His essence, or (ii) it has to be caused by something external to essence. Importantly, Aquinas does not take into account here that existence could be part of essence.

\section{Summa Contra Gentiles}

I, c. 42

The ninth argument

Adhuc, Si sunt duo dii, aut hoc Next, if there are many gods, then nomen Deus de utroque either this name 'God' is predipraedicatur univoce aut cated of these two univocally or aequivoce. Si aequivoce, hoc est equivocally. If equivocally, it is praeter intentionem praesentem; beyond our current intention: nam nihil prohibet rem quamlibet since nothing prevents any thing quolibet nomine aequivoce being named by any name, pronominari, si usus loquentium vided that this is allowed by the admittat. Si autem dicatur speaker's habit. But if it is prediunivoce, oportet quod de utroque cated univocally, it is necessary praedicetur secundum unam that it is predicated of these two rationem; et sic oportet quod in according to the same concept, utroque sit una natura secundum and thus, one nature according to rationem. Aut igitur haec natura the concept must be in them. So est in utroque secundum unum either this nature is in these two esse, aut secundum aliud et aliud. according to one existence, or not. $\mathrm{Si}$ secundum unum, ergo non If the former is the case, then erunt duo, sed unum tantum; there are no two gods but only duorum enim non est unum esse, one: the existence of two ones is si substantialiter distinguantur. Si not one, if they would differ acautem est aliud et aliud esse in cording to substance. Yet if the utroque, ergo neutrum erit sua existence in them is different in quidditas vel suum esse; sed hoc each case, neither of them would 
oportet in Deo ponere, ut be His own essence or His exisprobatum est; ergo neutrum tence; yet this should be assumed illorum duorum est hoc, quod about God, as it has been demonintelligimus nomine Dei. Sic strated. Hence, neither of them is igitur impossibile est ponere duos something we mean by God. deos. (Scg c.42, p.39, col.1, 1.40- Thus, it is impossible to assume 57 ; col.2, 1.1-5) two gods.

The premises of Thomas's reasoning are: “Aut igitur haec natura est in utroque secundum unum esse, aut...", i.e.

(5) $\forall x \forall y(\mathrm{D}(x) \wedge \mathrm{D}(y) \rightarrow((\operatorname{ess}(x)=\operatorname{ess}(y) \wedge \operatorname{ex}(x)=\operatorname{ex}(y)) \vee(\operatorname{ess}(x)=$ $\operatorname{ess}(y) \wedge \operatorname{ex}(x) \neq \operatorname{ex}(y)))$

“Si secundum unum...", i.e.,

(6) $\forall x \forall y(\operatorname{ess}(x)=\operatorname{ess}(y) \wedge \operatorname{ex}(x)=\operatorname{ex}(y) \rightarrow x=y)$

"duorum enim..." is a version of the principle of the one-to-one correlation between being and its existence, i.e.

(7) $\forall x \forall y(x \neq y \rightarrow \operatorname{ex}(x) \neq \operatorname{ex}(y))$

Our interpretation of (7) may raise certain doubts. Should not identity of two objects mean that they differ according to substance? The answer depends of course on what is the meaning of the term 'substantialiter' here. It 
seems that Thomas means here that we have two substances (i.e. two individuals). If we read the sentence as duorum enim non est unum esse, si essentialiter distinguantur, then proofs for the uniqueness of God would be simply unintelligible. Secondly, Aquinas assumes (7) in Scg: the evidence is in such text as habet enim res unaquaeque in seipsa esse proprium ab omnibus aliis distinctum (Scg, c.14, p.15, col.1, 1.20-22 - "For every thing has in itself its own existence, different from any other [existences]") or Esse proprium cuiuslibet rei est tantum unum (Scg c.42, p.40, col.1, 1.1-2 "Existence proper to every thing is only one").

"Si autem..." is not clear: the consequent of this sentence can mean "ergo neutrum erit sua quidditas, aut neutrum erit suum esse", i.e.

$\forall x \forall y(\operatorname{ess}(x)=\operatorname{ess}(y) \wedge \operatorname{ex}(x) \neq \operatorname{ex}(y) \rightarrow$
$(x \neq \operatorname{ess}(x) \wedge y \neq \operatorname{ess}(y)) \vee(x \neq \operatorname{ex}(x) \wedge y \neq \operatorname{ex}(y)))$

It seems that Thomas treats this formula as a logical theorem ${ }^{7}$, in this case-speaking in a modern manner-the conclusion follows from the elementary theory of identity. But in fact it is not a logical theorem. Thus, the consequent could be then read as "ergo neutrum erit aut sua quidditas, aut suum esse", i.e.,

$\forall x \forall y(\operatorname{ess}(x)=\operatorname{ess}(y) \wedge \operatorname{ex}(x) \neq \operatorname{ex}(y) \rightarrow$ $(x \neq \operatorname{ess}(x) \vee x \neq \operatorname{ex}(x)) \wedge(y \neq \operatorname{ess}(y) \vee y \neq \operatorname{ex}(y)))$

Unfortunately, this also is not a logical theorem. So let us try this way: the consequent will be "ergo neutrum sua quidditas erit suum esse", i.e.

$\forall x \forall y(\operatorname{ess}(x)=\operatorname{ess}(y) \wedge \operatorname{ex}(x) \neq \operatorname{ex}(y) \rightarrow(\operatorname{ess}(x) \neq \operatorname{ex}(x) \wedge \operatorname{ess}(y) \neq \operatorname{ex}(y)))$

But this is not a logical theorem, either. We can read the consequent as speaking of some of them: so "neutrum" is wrong here.

(8) $\forall x \forall y(\operatorname{ess}(x)=\operatorname{ess}(y) \wedge \operatorname{ex}(x) \neq \operatorname{ex}(y) \rightarrow(\operatorname{ess}(x) \neq \operatorname{ex}(x) \vee \operatorname{ess}(y) \neq$ $\operatorname{ex}(y)))$

\footnotetext{
${ }^{7}$ Strictly speaking, a theorem of logic enriched by constants 'ess' and 'ex'.
} 
It is easy to demonstrate that that this is a theorem of the elementary theory of identity (enriched by constants 'ess' and 'ex'). It can also be demonstrated that from (5), (7) and (8), (!) does not follow, unless we add premise (4). So Thomas himself adds this in the argument we are considering.

\section{Comparison and further analysis}

From what we have said so far, it follows that we have the following proofs of the first type:

$$
\text { S.th.: (1), (2) } ⺊(!)
$$

Scriptum:(2), (3), (4) F(!)

Scg: (4), (5), (7), (8) $\vdash(!)$

We can ask which argument is based on the weakest premises. Now, one can demonstrate that (5) is equivalent to (2) and that (7) implies (3). So (2) is a premise of all three proofs, and the argument from Scriptum is better than the argument from $\mathrm{Scg}$.

Recall that in the comments on the first proof from S.th. we have said that lack of accidents in a being entails, according to Aquinas, that this being is its essence. It is worth considering this issue for the following reason: since all three proofs are based on the theorem stating that essences of God-like beings are identical, one should prefer the proof containing the smallest number of premises, i.e. the first proof from S.th. In other words, assuming that essences of God-like beings are identical, it suffices to prove that every such object is its own essence.

\section{Deus est sua essentia}

Hereafter, we shall try to analyze certain arguments form chapter 23 of $S c g$ ("That in God there are no accidents").

One could ask why we focus on chapter 23 and not on chapter 21 ("That God is His essence"). Now, in the latter Thomas gives us five arguments for the theorem that God is his essence. Yet the fifth is very unclear; in the fourth Aquinas allows himself to refer at most to chapter 13, but it is insufficient since chapter 13 is devoted only to the causes of motion in the Aristotelian sense; the third is the counterpart of the one from S.th. q.3, a.3 we have already quoted; the second refers to chapter 23 (which we will com- 
ment on below); so there remains the first which refers to chapter 18 ("That in God there is no composition").

Quod in Deo nulla sit compositio (Scg, c.18).

This chapter consists of seven arguments. The third and the fourth are unclear:

Omne compositum est potentia|[The third argument] Every comdissolubile, quantum est ex position is potentially decomratione compositionis, licet in posable, if it exists in virtue of quibusdam sit aliquid aliud being composed, although in cerdissolutioni repugnans. Quod tain things there is something autem est dissolubile est in else, which resists decomposition potentia ad non-esse; quod Deo in them. What is decomposable, is non competit, cum sit per se potentially not existent, which necesse esse. Non est ergo in eo does not pertain to God, since $\mathrm{He}$ aliqua compositio.

Amplius, omnis compositio it is necessary by itself that $\mathrm{He}$ indiget aliquo componente; si exists]. Hence, there is no compoenim compositio est, ex pluribus sition in Him.

est. Quae autem secundum se sunt [The fourth argument] Similarly, plura, in unum non conveniunt, every composition requires somenisi ab aliquo componente thing composing it, for if there is uniantur. Si igitur compositus composition, it is such in virtue of esset Deus, haberet the many. Now, things that are by componentem; non enim ipse themselves numerous, would not seipsum componere posset, quia have been unified if they had not nihil est causa suiipsius; esset been unified by something unifyenim prius seipso, quod est ing them. So, if God were comimpossibile. Componens autem posed, He would have something est causa efficiens compositi. composing Him, for He could not Ergo Deus haberet causam compose Himself, as nothing is efficientem; et sic non esset causa the cause of itself: otherwise $\mathrm{He}$ prima, quod supra habitum est. would exist before Himself, (Scg c.18, p.17, col.2, 1.7-28) which is impossible. And a thing composing is the efficient cause of a thing composed. Hence, God would have an efficient cause, as 
a result of which he would not be the first cause, for which we have agreed above.

The first argument is also unclear.

The fifth is may be summarized as follows. The more simple a thing is, the more perfect it is. Cause is more perfect then its effect. God does not have any cause; hence, He is the most perfect being. Ergo, God is the simplest being. This argument fails for Thomas proved neither that God is the cause of everything nor that he is unique. Assuming that proofs for the existence of God in chapter 13 are sound, he at best demonstrated that He has no cause. For example, let domain $\mathrm{D}=\{a, b, c\}$ be given; and let $a$ be a cause of $c$ and $b$ be a cause of $c$ as well. We have here two God-like beings, but from the principle "cause is more perfect then its effect" alone we cannot conclude which God-like being is more perfect.

The sixth argument has, in turn, unclear premises: God is the most perfect being. In composites, parts are imperfect as compared to the whole, therefore, such things cannot be the most perfect beings. Ergo, God is not a composite. So, let us take a look at the second and the seventh argument:

Item, omne compositum posterius |[c. 18, The second argument] est suis componentibus. Primum Also, every composite is posterior ergo ens, quod Deus est, ex nullis to its components. So the first becompositum est. (Scg c.18, p.17, ing, which is God, is not comcol.2, 1.4-6) posed from anything.

Words 'primum', 'posterius' suggest some kind of order (not necessarily a linear one, though the text suggests so). Is this a causal order ("the first" would mean here "without any cause")? It seems not: otherwise we would liken it to the fourth argument from chapter 18, which we have already quoted.

Item, ante multitudinem oportet|[The seventh argument] Moreinvenire unitatem. In omni autem over, before each multiplicity one composito est multitudo. Igitur should find unity. But in every oportet id, quod est ante omnia, composite is multiplicity. So it is scilicet Deum, omni compositione necessary that this, which is becarere. (Scg c.18, p.17, col.2, fore everything, namely God, is 
The expression 'ante omnia' entails uniqueness. Yet, interestingly, the parallel text from S.th . q.3, a.7, p.23, col.1, 1.44-45 throws some light on the second argument: "omne compositum est posterius suis componentibus, et dependens ex eis". What is dependence (dependentia)? Recall the last argument from chapter 23. "Substance does not depend on accidents, though accidents depend on substance. But a thing that does not depend on something else, sometimes can be discovered as being without that other thing"-substantia non dependet ab accidente, quamvis accidens dependeat a substantia. Quod autem non dependet ab aliquo potest aliquando inveniri sine illo-Scg c.23, p.25, col.1, 1.39-43. It follows that if $x$ does not depend on $y$, than $x$ can exist without $y$; and, probably, if $x$ depends on $y$, than $x$ cannot exist without $y$. From this provisional explication of the notion of dependence we can conclude that Thomas holds:

(9) $\forall x$ ( $x$ is composed $\rightarrow \forall y$ ( $y$ is a component of $x \rightarrow x$ cannot exist without y)

and

$$
\forall x(\mathrm{D}(x) \rightarrow \neg \exists y(y \neq x \wedge x \text { cannot exist without } y))
$$

i.e.

$$
\forall x(\mathrm{D}(x) \rightarrow \forall y(x \text { cannot exist without } y \rightarrow x=y))
$$

where ' $\mathrm{D}(x)$ ' denotes ' $x$ is a God-like being'.

The problem lies in that if Aquinas substitutes accidents for $y$, then in the case of improper accidents, theorem (9) is false: if I have a beard, thensince this is for me a contingent accident-I can exist without my beard.

Now we have to turn to the chapter directly devoted to the question concerning accidents.

Quod in Deo non sit accidens 
Not all the proofs from this chapter deserve our attention. Certain versions of the first and the third have already been presented (S.th. q.3, a.6; see the section devoted to $S$. th.). The sixth appeals to simplicity. The fifth assumes, inter alia, that God is the cause of everything. God has no accidents; hence, $\mathrm{He}$ is his essence, since being such is more perfect than if $\mathrm{He}$ were not His essence. Cause is more perfect than its effect. God is the cause of everything. Ergo, God has no accidents. So let us analyze the fourth and the second argument.

The fourth argument from c. 23

\begin{tabular}{l|l|l} 
Cuicumque inest aliquid & Everything in which there is \\
accidentaliter, est aliquo modo, & something accidentally, is some- \\
secundum suam naturam, & how by its nature changeable; for \\
mutabile; accidens enim de se & accident is by its nature being in \\
natum est inesse et non inesse. Si & and not being in [i.e. by its nature \\
igitur Deus habet aliquid & it has potentiality for being in \\
accidentaliter sibi conveniens, & something, and also for not being \\
sequetur quod ipse sit mutabilis; & in something]. Hence, if God has \\
cuius contrarium supra de-- & something accidentally, it follows \\
monstratum est. (Scg c.23, p.25, & that He is changeable; whose op- \\
col.1, 1.14-21) & $\begin{array}{l}\text { position has been demonstrated } \\
\text { above. }\end{array}$
\end{tabular}

The sentence "accidens enim" can be interpreted as follows:

(P) $\forall y \forall x(y$ is an accident of $x \leftrightarrow x$ can be $y \wedge x$ may not be $y)$

Keeping in mind the characterization of accidents from the section devoted to $S$. th., it is obvious that $(\mathrm{P})$ is about improper accidents only. The "changeability" of $x$ consists in that $x$ can be yet may not be $y$-we can call it "modal changeability". I think it is worth referring here to Knuuttila's observation that in medieval philosophy (Aquinas included) the so called statistical interpretation of modality was favored, and, in particular, the famous "Principle of Plenitude". ${ }^{8}$ This explains Thomas's reasoning, particularly that of his "Third Way". The principle of plenitude can be formulated thus:

\footnotetext{
${ }^{8}$ Knuuttila 1982, 342-357.
} 
$\forall x \forall y\left(x\right.$ can be $y / x$ may not be $y \rightarrow \exists t\left(x\right.$ is $y$ at $t / \exists t^{\prime} x$ is not $y$ at $\left.\left.t^{\prime}\right)\right)$

Our interpretation needs some comment. The expression ' $x$ can be $y$ ' is connected with the non-modal expression ' $x$ is $y$ ' (or ' $x$ is $y$ at $t$ '). This formula can be interpreted, of course, in many ways. ${ }^{9}$ Since the chapter under consideration has to do with accidents, assume that 'is' expresses here a certain relation holding between a substance and accidents. In order to avoid introducing variables of different kinds, we will interpret ' $x$ is $y$ ' as 'accident $y$ pertains to $x$ '. In addition, we will assume that this relation is asymmetric. Recall also that $(\mathrm{P})$ is the definition of improper accident. Let me add that alternative formulations of the principle of plenitude are also allowed.

In chapter 13 Thomas tries to demonstrate that God, i.e., primus motor separatus, omnino immobilis, exists. Of course, one should ask what kind of motus is taken into account here. The answer is: at least each kind of physical motion in the Aristotelian sense, hence, e.g., if this accident is a quality $y$, then change from not-y to $y$ is a kind of motion (...ut probat, inducendo in singulis speciebus motus.(...) si autem secundum aliam speciem motus moveatur... etc. [Scg c.13, p.12, col.1, 1.33-34; p.13, col.1, 1.7-9; emphasis - TK]).

Now we can prove that there are no improper accidents in God.

Let ' $x$ MEy' denote ' $x$ can be $y$ '

' $x$ M-Ey' denotes ' $x$ may not be $y$ '

' $x$ E $y$ ' denotes ' $x$ is $y$ '

' $x$-Ey' denotes ' $x$ is not $y$ '

' $x$ Eyt' denotes ' $x$ is $y$ at $t$ '

' $x$-Eyt' denotes ' $x$ is not $y$ at $t$ '

' $y \mathrm{P} x$ ' denotes ' $y$ is $x$ 's improper accident'

' $\mathrm{D}(x)$ ' denotes ' $x$ is a God-like being'.

One must add that the proof of the theorem that improper accidents do not pertain to God should be based on the basic modal logic of the expressions ' $x$ can be $y / x$ may not be $y$ '. We will not, however, search for such a logic in Aquinas's writings: instead, we will simply treat ME, M-E, E, -E as primitive predicates.

\footnotetext{
${ }^{9}$ See, for example, Perzanowski 1993, 10-16.
} 
Apart from the definition of $\mathrm{P}$

(def. of P) $\quad \forall x \forall y(y \mathrm{P} x \leftrightarrow x \mathrm{ME} y \wedge x \mathrm{M}-\mathrm{E} y)$

we assume that

(God's immobilitas) $\quad \forall x \forall y\left(\mathrm{D}(x) \rightarrow \neg\left(\exists t x \mathrm{E} y t \wedge \exists t^{\prime} x\right.\right.$-Eyt'))

Our formalization assumes that the principle of plenitude consists of two propositions:

(Positive principle of plenitude) $\forall x \forall y(x \mathrm{ME} y \rightarrow \exists t x \mathrm{E} y t)$

(Negative principle of plenitude) $\forall x \forall y\left(x \mathrm{M}\right.$-Ey $\rightarrow \exists t^{\prime} x$-Eyt')

They entail:

(11) $\forall x \forall y\left(x \mathrm{ME} y \wedge x \mathrm{M}-\mathrm{E} y \rightarrow \exists t x \mathrm{E} y t \wedge \exists t^{\prime} x\right.$-E $\left.y t^{\prime}\right)$

From (def. of P), (God's immobilitas) and (11) it follows that

$$
\forall x(\mathrm{D}(x) \rightarrow \neg \exists y y \mathrm{P} x)
$$

Now we turn to the second argument that there are no accidents in God.

The second argument from c. 23

Amplius, Omne quod inest alicui|Similarly, everything being in accidentaliter, habet causam something accidentally has a quare insit, cum sit praeter cause in virtue of which it is in essentiam eius cui inest. Si igitur that thing, since it is outside of aliquid accidentaliter sit in Deo, that thing's essence. So if there oportet quod hoc sit per aliquam were something in God accidencausam. Aut ergo causa tally, it would have to be so in accidentis est ipsa divina virtue of some cause. And either substantia, aut aliquid aliud. $-\mathrm{Si} \mid$ the divine substance itself is such 
aliquid aliud, oportet quod illud a cause or something else. If agat in divinam substantiam. something else is such a cause, it Nihil enim inducit aliquam is necessary that something else formam vel substantialem vel acts upon the divine substance. accidentalem, in aliquo For nothing can introduce any recipiente, nisi aliquo modo form-either substantial form or agendo in ipsum, eo quod agere accidental-into some being renihil aliud est quam facere ceiving that form, if not acting aliquid actu: quod quidem est upon that thing in some way, for per formam. Ergo Deus patietur to act is nothing else than to make et movebitur ab aliquo agente; something actual, and this process quod est contra praedeterminata is done through some form. (c. 13). (Scg c.23, p.24, col.2, Therefore, God will be acted $1.32-48)$ upon and moved by some agent, contrary to what has been established (in chapter 13).

In the comments on the first argument from S.th. we said that the principle 'what is outside of essence, has a cause' was not explained. Yet, if we refer to chapter 15 we can agree that Thomas assumes-regarding improper accidents-the theorem analogous to a certain proposition from chapter 15 . Which proposition? First let us look at the following text from this chapter (this is a fragment of the fourth argument for the eternity of God):

(1) Videmus in mundo quaedam quae sunt possibilia esse et non esse, scilicet generabilia et corruptibilia.

(2) Omne autem quod est possibile esse, causam habet;

(3) quia, cum de se aequaliter se habeat ad duo, scilicet esse et non esse, oportet, si ei approprietur esse, quod hoc sit ex aliqua causa.

(Scg. c.15, p.15, col.2, 1.42-49)
(1) We can see in this world certain things that can be and may not be, i.e., coming into existence and passing away.

(2) Yet everything that is a possible being [vel: for which it is possible that it exists], has a cause.

(3) Therefore, since it in itself refers equally to existence and to non-existence, it is necessary that if it gains existence, then it does so in virtue of some cause. 
Sentence (1) is not unproblematic: we cannot exclude that-similarly as it is e.g. in sentence (2) - it says about de re logical modality (as opposed to ontological modality). Let ' $\mathrm{E}(x)$ ' denote ' $x$ exists', ' $\mathrm{ME}(x)$ ' denote ' $x$ is a possible being', ' $y$ CAU $x$ ' denote ' $y$ is a cause of $x$ ', ' $\diamond$ ' denote 'it is possible that'. Sentence (2) can be formalized as:

$\forall x(\diamond \mathrm{E}(x) \rightarrow \exists y$ y CAU $x)$

or as:

$\forall x(\mathrm{ME}(x) \rightarrow \exists y$ y $\mathrm{CAU} x)$

But this does not seem to be true. Thomas in sentence (3) adds that having a cause holds in case of existing things. What is something which 'in itself refers equally to existence and to non-existence'? It seems that this expression should be understood as follows: this thing can exist and may not exist (or: it is possible that it exists, and it is possible that it does not exist). This characterization is just the characterization of contingent being, and such modality occurs in sentence (2) under somewhat misleading name "possibile esse". Let ' $\mathrm{ME}(x)$ ' not denote ' $x$ is a possible being', and ' $x$ can exist'; let 'M-E $(x)$ ' denote ' $x$ may not exist'; ' $\mathrm{P}(x)$ ' denote ' $x$ is contingent'. The definition of contingency will be:

$\mathrm{P}(x):=\mathrm{ME}(x) \wedge \mathrm{M}-\mathrm{E}(x)$

or:

$\mathrm{P}(x):=\diamond \mathrm{E}(x) \wedge \diamond \neg \mathrm{E}(x)$

Sentence (3) says that what is contingent and exists, has a cause:

$$
\forall x(\mathrm{P}(x) \wedge \mathrm{E}(x) \rightarrow \exists y \text { y CAU } x)
$$

This proposition gives us clue: As far as improper accidents are concerned, assume that

$\forall x \forall y$ ( $x$ can be $y \wedge x$ may not be $y \wedge x$ is $y \rightarrow \exists z z$ is a cause of $y$ in $x$ )

Formally, 
The problem of transition from the sentence 'God has no cause' to the one 'nothing in God has any cause' remains. It is worth noticing that in the argument we analyze, Aquinas makes use of a completely different premise, namely, that occurrence of the relation of causality entails occurrence of change in the object upon which this cause acts. In order to make this proposition more similar to (13), we formalize it as:

$$
\forall x \forall y \forall z\left(z \mathrm{CAU} y x \rightarrow \exists t\left(x \mathrm{E} y t \wedge \exists t^{\prime}\left(t \neq t^{\prime} \wedge x \text {-E } y t^{\prime}\right)\right)\right)
$$

Moreover, as we can see, from (13) and (14) we have that something, which can be $y$ and may not be $y$, and is $y$, sometimes is not $y$ ! Namely,

$$
\forall x \forall y(x \mathrm{ME} y \wedge x \mathrm{M}-\mathrm{E} y \wedge x \mathrm{E} y \rightarrow \exists t x \text {-Eyt })
$$

Although theorem (15) is not identical with the negative principle of plenitude (more precisely, it follows from this principle), it seems that it expresses a similar conception of modality to the one expressed in the fourth argument of chapter 23. Therefore, we do not have a proof for the lack of improper accidents in God, the proof of which can be independent of such a nonstandard interpretation of modality.

Another proof for the lack of improper accidents in God can be made using (13), (14), (def. of P) and (God's immobilitas). It should be pointed out here that the proposition that is to be proved will differ from the one that has been given above (see the section devoted to the fourth argument from c. 23), namely (12):

$$
\forall x \forall y(\mathrm{D}(x) \rightarrow \neg y \mathrm{P} x)
$$

The theorem that is to be proved will be:

$$
\forall x \forall y(\mathrm{D}(x) \rightarrow \neg(y \mathrm{P} x \wedge x \mathrm{E} y))
$$

These two formulae have very similar senses: the latter says that an allegedly God-like being's accidents are not improper ones, whereas the former says that nothing is a God-like being's accident. 
So far we have taken into account improper accidents. What about the proper ones? The second part of the second argument from chapter 23 is:

Si autem ipsa divina substantia| If the divine substance itself is the est causa accidentis quod sibi cause of accidents which are in inest; impossibile autem est quod this substance; it is impossible for sit causa illius, secundum quod this substance to be the cause of est recipiens ipsum; quia sic idem this accident since it itself resecundum idem, faceret seipsum ceives this accident, and then the in actu; ergo oportet, si in Deo same and under the same aspect est aliquod accidens, quod would make itself actual. Hence, secundum aliud et aliud recipiat it is necessary-if there is any acet causet accidens illud; sicut cident in God-that this subcorporalia recipiunt propria stance under one aspect receives accidentia per naturam materiae, this accident, and under another et causant per formam. Sic igitur Deus erit compositus; cuius contrarium superius probatum est. (Scg c.23, p.24, col.2, 1.48$55 ; \mathrm{p} .25$, col.1, 1.1-5)

causes this accident, as, for ex-
ample, corporeal beings receive
proper accidents through the na-
ture of matter, and cause them
through form. Thus, God will be
composite; whose opposition has
been demonstrated above.

The problem is that Aquinas seems to assume that there are proper accidents of certain immaterial substances, i.e. angels. In De ente c. 6 he writes:

...et quia in istis substantiis $\mid$...and since in these substances quidditas non est idem quod esse, [i.e. immaterial ones] their esideo sunt ordinabiles in sence is not the same as their praedicamento; et propter hoc existence, we can place them in invenitur in eis genus, species et the order of categories, and in differentia, quamvis earum virtue of this we discover in them differentiae propriae nobis kind, species and difference, occultae sint (...). Accidentia though we do not know what their autem propria substantiarum proper differences look like (...). 
immaterialium nobis ignota sunt, not know the proper accidents of unde differentiae earum nec per immaterial substances; hence, se nec per accidentales their differences can be signified differentias nobis significari neither in themselves, nor through possunt. (De ente c.6, p.28, 1.31- accidental differences. $35 ;$ p.29, 1.3-6)

That their proper accidents are not known by us does not mean that they do not exist. According to Thomas, angels are not composed of matter and form. But the solution is simple: proper accidents "follow" from nature, hence, they cannot individuate angels within one species - in other words, if they were different proper accidents, we would have different natures.

\section{Summary}

We have not gained a sound argument that there are no accidents in God, i.e., that God is His essence. Worse, Aquinas seems to take it for certain that God-like beings have the same essence. Therefore, the arguments we have called the arguments of the first type, seem very problematic.

\section{Appendix}

Formal proofs

The proofs will be presented according to the following scheme. First, (i) via dictum de omni, we omit (all or some) general prefix quantifiers, then (ii) using metatheorem (M) we deduce from such open formulas the theorem which is to be proved, and which will be also an open formula, and finally (iii) we use the rule of generalization. Since the relation of deducibility is transitive, from premises in a closed form, we obtain the theorem that is to be proved.

Now the aforementioned metatheorem $(\mathrm{M})$ is:

If $z_{1}, \ldots, z_{n}$ are all the free variables (different from each other) in the formula $A$, and $b_{1}, \ldots, b_{n}$ are different individual terms which do not occur in 
formulas from set $X \mathrm{U}\{A, B\}$, and $B\left(z_{1} / b_{1}, \ldots, z_{n} / b_{n}\right) \in C n_{C P C-I}(X \mathrm{U}\{$ $\left.\left.A\left(z_{1} / b_{1}, \ldots, z_{n} / b_{n}\right)\right\}\right)$,

then

$` A \rightarrow B^{`} \in C n_{C P C-I}(X)^{10}$

Where $\mathrm{Cn}_{\mathrm{CPC}-\mathrm{I}}$ is the consequence operator of (classic) first-order predicate calculus.

For brevity's sake, we omit in proofs part (i) and (iii), and we will write simply about substitutions (of individual terms), but such substitutions are indeed made on open counterparts of premises.

\section{Ad Scriptum:}

We prove that if (2), (3) and (4) are the case, so is (!).

1. $\mathrm{D}(a) \wedge \mathrm{D}(b) \quad$ (assumption, substitution)

2. $a \neq b \wedge \operatorname{ess}(a)=\operatorname{ess}(b) \rightarrow \operatorname{ex}(a) \neq \operatorname{ex}(b)((3)$, substitution)

3. $\operatorname{ess}(a)=\operatorname{ess}(b) \wedge \operatorname{ex}(a)=\operatorname{ex}(b) \rightarrow a=b \quad$ (2, classic propositional calculus $[=\mathrm{CPC}])$

4. $\mathrm{D}(a) \rightarrow \operatorname{ess}(a)=\operatorname{ex}(a) \quad((4)$, substitution)

5. $\mathrm{D}(b) \rightarrow \operatorname{ess}(b)=\operatorname{ex}(b) \quad$ (as above)

6. $\operatorname{ess}(a)=\operatorname{ex}(a) \wedge \operatorname{ess}(b)=\operatorname{ex}(b) \quad(1,4,5, \mathrm{CPC})$

7. $\operatorname{ess}(a)=\operatorname{ess}(b) \rightarrow a=b(3,6$, the rule of replacement of identicals, CPC)

8. $\mathrm{D}(a) \wedge \mathrm{D}(b) \rightarrow \operatorname{ess}(a)=\operatorname{ess}(b) \quad((2)$, substitution $)$

9. $a=b \quad(1,8,9, \mathrm{CPC})$

Ad Summa contra gentiles I, c. 42, the ninth argument:

First we prove by reductio that (8) is the case:

1. $\operatorname{ess}(a)=\operatorname{ess}(b) \wedge \operatorname{ex}(a) \neq \operatorname{ex}(b)$

2. $\neg(\operatorname{ess}(a) \neq \operatorname{ex}(a) \vee \operatorname{ess}(b) \neq \operatorname{ex}(b))$

3. $\operatorname{ess}(a)=\operatorname{ex}(a) \wedge \operatorname{ess}(b)=\operatorname{ex}(b)$ (assumption, substitution)

(assumption, substitution)

(2, CPC)

${ }^{10}$ See Batog, 1994, 164. 
4. $\operatorname{ess}(a)=\operatorname{ess}(b) \wedge \operatorname{ess}(a) \neq \operatorname{ess}(b) \quad(1,3$, the rule of replacement of identicals)

We obtain a contradiction, hence-since (apart from CPC) we use only the rule of replacement of identicals-(8) is a theorem of the elementary theory of identity.

Now we prove (!) on the basis of (4), (5), (7) and (8):

Proof:

1. $\mathrm{D}(a) \wedge \mathrm{D}(b) \rightarrow((\operatorname{ess}(a)=\operatorname{ess}(b) \wedge \operatorname{ex}(a)=\operatorname{ex}(b)) \vee(\operatorname{ess}(a)=\operatorname{ess}(b) \wedge$ $\operatorname{ex}(a) \neq \operatorname{ex}(b))$ $((5)$, substitution)

2. $\mathrm{D}(a) \rightarrow \operatorname{ess}(a)=\operatorname{ex}(a)$ ((4), substitution)

3. $\mathrm{D}(b) \rightarrow \operatorname{ess}(b)=\operatorname{ex}(b)$ (as above )

4. $a \neq b \rightarrow \operatorname{ex}(a) \neq \operatorname{ex}(b)$

5. $\mathrm{D}(a) \wedge \mathrm{D}(b)$ ((7), substitution)

6. $\operatorname{ex}(a)=\operatorname{ex}(b) \rightarrow a=b$ (assumption)

7. $(\operatorname{ess}(a)=\operatorname{ess}(b) \wedge \operatorname{ex}(a)=\operatorname{ex}(b)) \vee(\operatorname{ess}(a)=\operatorname{ess}(b) \wedge \operatorname{ex}(a) \neq \operatorname{ex}(b))$

$(1,5$, modus ponens $)$

8. $\operatorname{ess}(a)=\operatorname{ess}(b) \wedge \operatorname{ex}(a) \neq \operatorname{ex}(b) \rightarrow$ $(\operatorname{ess}(a) \neq \operatorname{ex}(a) \vee \operatorname{ess}(b) \neq \operatorname{ex}(b))$ ((8), substitution)

9. $\operatorname{ess}(a)=\operatorname{ex}(a) \wedge \operatorname{ess}(b)=\operatorname{ex}(b) \rightarrow$

$\neg(\operatorname{ess}(a)=\operatorname{ess}(b) \wedge \operatorname{ex}(a) \neq \operatorname{ex}(b))$

10. $\operatorname{ess}(a)=\operatorname{ex}(a) \wedge \operatorname{ess}(b)=\operatorname{ex}(b)$ $(5,2,3, \mathrm{CPC})$

11. $\neg(\operatorname{ess}(a)=\operatorname{ess}(b) \wedge \operatorname{ex}(a) \neq \operatorname{ex}(b))$

$(9,10$, modus ponens $)$

12. $\operatorname{ess}(a)=\operatorname{ess}(b) \wedge \operatorname{ex}(a)=\operatorname{ex}(b)$

$(7,11, \mathrm{CPC})$

13. $\operatorname{ex}(a)=\operatorname{ex}(b)$

14. $a=b$

$(12, \mathrm{CPC})$

$(13,6$, modus ponens $)$

Notice here that (8) is in fact redundant, since one can make a much simpler proof of (!) in virtue of (5)'s being equivalent to (2)-we shall omit the simple proof for such equivalence.

Ad The fourth argument from c. 23:

From (def. of P), (God's immobilitas) and (11) it follows that

$\forall x(\mathrm{D}(x) \rightarrow \neg \exists y$ y $\mathrm{P} x)$ 
From classic predicate calculus, this formula is equivalent to:

$\forall x \forall y(\mathrm{D}(x) \rightarrow \neg y \mathrm{P} x)$

Thus, the proof will be as follows:

1. $b \mathrm{P} a \leftrightarrow a \mathrm{ME} b \wedge a \mathrm{M}-\mathrm{E} b \quad$ (def. of $\mathrm{P}$ )

2. $a \mathrm{ME} b \wedge a \mathrm{M}-\mathrm{E} b \rightarrow \exists t a \mathrm{E} b t \wedge \exists t^{\prime} a$-E $b t^{\prime} \quad$ ((11), substitution)

3. $\mathrm{D}(a) \rightarrow \neg\left(\exists t a \mathrm{E} b t \wedge \exists t^{\prime} a\right.$-E $\left.b t^{\prime}\right) \quad$ (God's immobilitas, substitution)

4. $\mathrm{D}(a)$ (assumption)

5. $\neg\left(\exists t a \mathrm{E} b t \wedge \exists t^{\prime} a-\mathrm{E} b t^{\prime}\right)$

$(3,4$, modus ponens $)$

6. $b \mathrm{P} a \rightarrow \exists t a \mathrm{E} b t \wedge \exists t^{\prime} a-\mathrm{E} b t^{\prime}$

$(1,2, \mathrm{CPC})$

7. $\neg b \mathrm{~Pa}$

$(5,6, \mathrm{CPC})$

Ad The second argument from c. 23:

We prove that (15) follows from (13) and (14):

1. $\forall z\left(z \mathrm{CAU} b a \rightarrow \exists t\left(a \mathrm{E} b t \wedge \exists t^{\prime}\left(t \neq t^{\prime} \wedge a\right.\right.\right.$-E $\left.\left.\left.b t^{\prime}\right)\right)\right)$ tion)

2. $a \mathrm{ME} b \wedge a \mathrm{M}-\mathrm{E} b \wedge a \mathrm{E} b \rightarrow \exists z z \mathrm{CAU} b a$

3. $a \mathrm{ME} b \wedge a \mathrm{M}-\mathrm{E} b \wedge a \mathrm{E} b$

4. $\exists z z \mathrm{CAU} b a$

((13), substitution)

5. $\forall z\left(z \mathrm{CAU} b a \rightarrow \exists t\left(a \mathrm{E} b t \wedge \exists t^{\prime}\left(t \neq t^{\prime} \wedge a-\mathrm{E} b t^{\prime}\right)\right)\right) \rightarrow$

$\left(\exists z z \mathrm{CAU} b a \rightarrow \exists t\left(a \mathrm{E} b t \wedge \exists t^{\prime}\left(t \neq t^{\prime} \wedge a\right.\right.\right.$-E $\left.\left.\left.b t^{\prime}\right)\right)\right) \quad(\mathrm{CPC}-\mathrm{I})$

6. $\exists t\left(a \mathrm{E} b t \wedge \exists t^{\prime}\left(t \neq t^{\prime} \wedge a\right.\right.$-E $\left.\left.b t^{\prime}\right)\right)$

$(1,4,5$, modus ponens $)$

7. $\exists t\left(a \mathrm{E} b t \wedge \exists t^{\prime}\left(t \neq t^{\prime} \wedge a-\mathrm{E} b t^{\prime}\right)\right) \rightarrow$

$\exists t a \mathrm{E} b t \wedge \exists t, t^{\prime}\left(t \neq t^{\prime}\right) \wedge \exists t^{\prime} a-\mathrm{E} b t^{\prime}$ (assumption)

8. $\exists t a \mathrm{E} b t \wedge \exists t, t^{\prime}\left(t \neq t^{\prime}\right) \wedge \exists t^{\prime} a-\mathrm{E} b t^{\prime} \rightarrow \exists t^{\prime} a$-E $b t^{\prime} \quad$ (CPC)

9. $\exists t^{\prime} a-\mathrm{E} b t^{\prime}$

$(6,7,8, \mathrm{CPC}$, modus ponens)

Finally, we prove (16) on the basis of (13), (14), (def. of P) and (God's immobilitas):

1. $\forall z\left(z \mathrm{CAU} b a \rightarrow \exists t\left(a \mathrm{E} b t \wedge \exists t^{\prime}\left(t \neq t^{\prime} \wedge a\right.\right.\right.$-E $\left.\left.\left.b t^{\prime}\right)\right)\right) \quad((14)$, substitution) 
2. $a \mathrm{ME} b \wedge a \mathrm{M}-\mathrm{E} b \wedge a \mathrm{E} b \rightarrow \exists z z \mathrm{CAU} b a$

3. $b \mathrm{P} a \leftrightarrow a \mathrm{ME} b \wedge a \mathrm{M}-\mathrm{E} b$

4. $\mathrm{D}(a) \rightarrow \neg\left(\exists t a \mathrm{E} b t \wedge \exists t^{\prime} a\right.$-E $\left.b t^{\prime}\right)$ ((13), substitution) tion)

5. $\mathrm{D}(a)$ (assumption)

6. $\neg\left(\exists t a \mathrm{E} b t \wedge \exists t^{\prime} a\right.$-E $\left.b t^{\prime}\right)$

(4, 5, modus ponens)

7. $b \mathrm{P} a \wedge a \mathrm{E} b \rightarrow \exists z z \mathrm{CAU} b a$ $(2,3, \mathrm{CPC})$

8. $\forall z\left(z \mathrm{CAU} b a \rightarrow \exists t\left(a \mathrm{E} b t \wedge \exists t^{\prime}\left(t \neq t^{\prime} \wedge a\right.\right.\right.$-E $\left.\left.\left.b t^{\prime}\right)\right)\right) \rightarrow$ $\left(\exists z z \mathrm{CAU} b a \rightarrow \exists t\left(a \mathrm{E} b t \wedge \exists t^{\prime}\left(t \neq t^{\prime} \wedge a\right.\right.\right.$-E $\left.\left.\left.b t^{\prime}\right)\right)\right) \quad$ (CPC-I)

9. $\exists t\left(a \mathrm{E} b t \wedge \exists t^{\prime}\left(t \neq t^{\prime} \wedge a\right.\right.$-E $\left.\left.b t^{\prime}\right)\right) \rightarrow$

$\exists t a \mathrm{E} b t \wedge \exists t, t^{\prime}\left(t \neq t^{\prime}\right) \wedge \exists t^{\prime} a-\mathrm{E} b t^{\prime}$ (def. of $\mathrm{P}$, substitution)

(God's immobilitas, substitu-

10. $\exists t a \mathrm{E} b t \wedge \exists t, t^{\prime}\left(t \neq t^{\prime}\right) \wedge \exists t^{\prime} a-\mathrm{E} b t^{\prime} \rightarrow$

$\exists t a \mathrm{E} b t \wedge \exists t^{\prime} a-\mathrm{E} b t^{\prime}$

11. $\exists z z \mathrm{CAU} b a \rightarrow \exists t\left(a \mathrm{E} b t \wedge \exists t^{\prime}\left(t \neq t^{\prime} \wedge a\right.\right.$-E $\left.\left.b t^{\prime}\right)\right)(1,8$, modus ponens )

12. $b \mathrm{P} a \wedge a \mathrm{E} b \rightarrow \exists t a \mathrm{E} b t \wedge \exists t^{\prime} a$-E $b t^{\prime} \quad \quad$ (7, 9, 10, 11, modus ponens)
13. $\neg(b \mathrm{P} a \wedge a \mathrm{E} b)$
$(6,12, \mathrm{CPC})$

\section{REFERENCES}

Original texts of St. Thomas:

De ente et essentia, Taurini: Marietti MCMXXVI

Scriptum super libros Sententiarum Magistri Petri Lombardi episcopi parisiensis, editio nova cura R.P.Mandonnet OP, t.I, Parisiis: P. Lethielleux 1929

Summa contra gentiles seu de veritate catholicae fidei, Taurini: Marietti MCMXXXVIII

Summa theologica, diligenter emendata de Rubeis, Billuart et aliorum notis selectis ornata, Pars $1^{\mathrm{a}}$, t.1, Taurini: Marietti $1894^{6}$

Summa theologiae, cura et studio Sac. Petri Caramello, cum textu ex recensione Leonina, Prima Pars, Taurini - Romae: Marietti 1950

Subsidiary literature cited:

Batog, T. 1994 Podstawy logiki, Poznan: Wydawnictwo Naukowe UAM, $2^{\text {nd }}$ edition. Kakol, T. 2006 „Analiza formalna wybranych dowodow na jedynosc Boga u swietego Tomasza z Akwinu", Studia Philosophiae Christianae, 1, 144-154. 
Knuuttila, S. 1982 "Modal logic", in N. Kretzmann, A. Kenny, J. Pinborg (eds.), The Cambridge History of Later Medieval Philosophy, Cambridge: Cambridge University Press, 342-357.

Perzanowski, J. 1993 "Locative ontology", Parts I-III, Logic and Logical Philosophy, Vol. 1, 7-94.

Plantinga, A. 1980 Does God Have A Nature?, Marquette: Marquette University Press.

Weisheipl, J.A. 1983 Friar Thomas d'Aquino: His Life, Thought, and Works. With corrigenda et addenda ( $2^{\text {nd }}$ ed.), Washington: Catholic University of America Press. 
